\title{
SSynthesis
}

International Scientific Conference of IT and Business-Related Research

\section{ACCESS TO FINANCIAL SOURCES IN SERBIA THE USE OF MEZZANINE INSTRUMENTS}

\author{
PRISTUP IZVORIMA FINANSIRANJA U SRBIJI: \\ PRIMENA INSTRUMENATA MEZANINA \\ Goranka Knežević1 Isidora Ljumović ${ }^{2}$, Vladan Pavlović ${ }^{3}$ \\ ${ }^{1}$ Singidunum University, Belgrade, Serbia \\ ${ }^{2}$ Institute of Economic Sciences, Belgrade, Serbia \\ ${ }^{3}$ University of Pristina, Faculty of Economics (dislocated in Kosovska Mitrovica), Serbia
}

\begin{abstract}
:
Access to sources of finance is one of the most important criteria used to determine the quality of the investment climate in some country. This issue is of paramount importance for both domestic and foreign investors. The paper underlines that besides traditional and pure forms of finance such as debt and equity, there are also hybrid forms that are widely used in developed countries. Such types of contracts are called mezzanine instruments and have the characteristics of both debt and equity. Their flexibility, lower issuance costs and lack of specific laws in this area, represent their competitive advantage over other forms of finance. The authors shall discuss whether mezzanine finance instruments could be used in Serbia and shall attempt to demonstrate that this form of finance is an adequate solution to be implemented in certain Serbian companies following the privatization process.
\end{abstract}

\section{Key words:}

mezzanine instruments, financing, small and medium-sized enterprises.

\section{Apstrakt:}

Pristup izvorima finansiranja predstavlja jedan od najvažnijih kriterijuma kada se vrši procena investicione klime u nekoj zemlji. Ovo pitanje je od ogromnog značaja kako za domaće tako i za strane investitore. Ovaj rad ukazuje na činjenicu da pored klasičnih i čistih formi finansiranja, kao što su obaveze i kapital, postoje i hibridni ugovori koji se često koriste u razvijenim zemljama radi finansiranja poslovnih ideja. Ove forme ugovora zovu se instrumenti mezanina i imaju karakteristike i obaveza i kapitala. Njihova fleksibilnost, niski troškovi zaključivanja mezanin ugovora, odnosno troškova emitovanja ovih instrumenta, kao i zakonska neregulisanost, čine njihovu konkurentsku prednost u odnosu na ostale forme finansiranja. Autori se bave pitanjem primene mezanin instrumenata u Srbiji i pokazuju da je ova forma finansiranja adekvatna za primenu u pojedinim srpskim preduzećima nakon procesa privatizacije.

\section{Ključne reči:}

instrumenti mezanina, finansiranje, mala i srednja preduzeća.

\section{Acknowledgements:}

This paper is a part of the results within research on project 179001 „Organizational and information support to the quality management system as a key factor in improving the competitiveness of domestic enterprises and ensuring their faster access to EU and world markets" financed by Ministry of education, science and technological development of the Republic of Serbia.

\section{INTRODUCTION}

Entrepreneurial activity usually starts with the business idea, but it is considered feasible provided that adequate financial resources are in compliance with the idea. The ability of enterprises to raise enough capital is mainly based on their profitability and financial prospects. Small enterprises have limited access to sources of finance, not only because of their size, but also due to the inability to issue stocks and satisfy the criteria for entering the stock market as issuers. In this specific case, obtaining a bank loan is the only source of external financing for many enterprises. Small and medium-sized enterprises (SMEs) are typically financed with the bank loans, especially in lessdeveloped economies. For instance, obtaining money to support projects through stocks issued, is quite a marginal form of financing for many Serbian investors, including the large companies (Pavlović \& Muminović, 2010). Serbian companies are most often the companies that operate with a low amount of owner's capital, which makes them risky for the banks and further reduces their ability to raise more funds. Bank loans could be a suitable source of finance for many companies, but they do not satisfy all their financing requirements. In order to become an attractive option for both parties, sources of finance should reach the expected return for the perceived level of risk. In reality, besides equity financing and debt financing, there are various other types of sources of finance such as mezzanine instruments. They are sometimes considered a substitute for traditional sources of financing. The term mezzanine is derived from the Italian word "mezzanine" which means a floor between the two main floors in a building. Within the area of corporate finance, this word is used figuratively as a term for hybrid instruments of financing that combine elements of debt and equity capital. Even though it is a relatively new form of finance, it cannot be considered a universal solution for all problems and all the companies. Namely, it is rather viewed as a series of instruments that suit different companies.

This paper shall present the definition and forms of mezzanine instruments, further elaborate on the typical usage of these instruments in developed countries, and the possibility and necessity of implementing such form of finance in Serbia. 


\section{MEZZANINE INSTRUMENTS}

Mezzanine finance instruments are rather difficult to define, because they represent a specific mix of tailor-made financial instruments. Nowadays, academicians and practitioners mostly rely on two main perspectives regarding mezzanine instruments. The first perspective (Clark, Creamer, Korver, McCormic, Ongena, Willis et al.) refers to the fact that mezzanine instruments need to possess characteristics of both debt and equity. According to these authors, junior subordinated debt and junk bonds are not considered mezzanine instruments. The other perspective considers the idea that all subordinated debt instruments are mezzanine. This paper shall present mezzanine instruments using the second point of view. The European Commission used this second perspective in its report, which was taken over from the Economic Research (2006) issued by Credit Suisse.

Typically, there are several mezzanine instruments with varying degrees of risk and return and their basic characteristics. Mezzanine instruments can range from products that are issued to the public (convertible bonds, bonds with options) to products that are placed privately (subordinated and participating loans, silent participations). However, they are usually classified according to their position in debt-equity relationship, as well as the risk and reward (illustrated in Image 1) matrix. The most important mezzanine finance instruments include: subordinated loans, participating loans, silent participation, profit participation rights, convertible bonds, and bonds with warrants.
Subordinated and participation loans are closer to debt form of mezzanine finance. Subordinated loan, as the simplest form of mezzanine finance, represents unsecured loan with the annual interest rate. However, since mezzanine is tailor-made, interest rate can be variable, or even expressed as a percentage of profit. In the case of default, the subordinated debt lender is paid out upon the settlement of all other creditors. On the other hand, participating loans are similar, but instead of the fixed interest rate, their remuneration is contingent upon the business results since they provide the lender with the right to participate in distribution of business results. Owing to this unique feature, participating loans usually have none or a low fixed interest rate of $1 \%$. In these loan contracts, business results can be defined on the basis of the revenue generated from sales, net income, cash flow or in any other specified way. Despite profit sharing, participating loans do not give rise to an ownership relation, and participation in losses is contractually excluded.

Silent participation is closer in legal form to equity since the distinguishing feature of this form of financing is that one or more persons take an equity stake in a company and receive part of the profit as compensation, without assuming any liability towards the company's creditors (European Commission, 2007, p. 6). This is probably the most flexible mezzanine instrument and the legal contract can take different forms. The contract shall define investor information rights, involvement in the process of business decision making or participation in loss coverage. Even though this instrument resembles participating loans in the case of the silent partnership, the investor receives equity share, usually participates in losses, and is involved in the decision making process.

Profit participation rights are equity investments that entitle the holder to rights over the company's assets (e.g. participation in profits or in the surplus on liquidation, subscription for new stock), but not the right to be consulted on business decisions (European Commission, 2007 p. 6; Credit Suisse, 2006, p. 18). Its main distinction from common shares is that this type of instruments does not provide voting rights and it has term (unless they

Image 1

Source: Authors

\begin{tabular}{|l|c|c|c|c|c|}
\hline \multicolumn{1}{|c|}{ Feature } & $\begin{array}{c}\text { Subordinated } \\
\text { loan }\end{array}$ & $\begin{array}{c}\text { Participating } \\
\text { loan }\end{array}$ & $\begin{array}{c}\text { Silent part- } \\
\text { nership }\end{array}$ & $\begin{array}{c}\text { Profit participa- } \\
\text { tion rights }\end{array}$ & $\begin{array}{c}\text { Bonds (convertible, } \\
\text { with warrants) }\end{array}$ \\
\hline Interest rate & Fixed & Fixed (1\%) & No & No & Yes \\
\hline Participation in profit & No & Yes & Yes & Yes ${ }^{*}$ & No \\
\hline Participation in losses & No & No & No* & No ${ }^{*}$ & No \\
\hline Ownership relation and decision making & No & No & Yes & Yes be converted \\
\hline Equity share & No & No & No* & No ${ }^{*}$ & No \\
\hline Decision making & Debt & Debt & Equity & Equity & Equity \\
\hline Type & & &
\end{tabular}

Table 1 Features of different mezzanine instruments

Note: ${ }^{*}$ Could be specified different in the contract

Source: Adapted from Economic Briefing No. 42, Mezzanine Finance - A Hybrid instrument with a Future, Credit Suisse Economic Research, 2006, p. 8 
are perpetual when they do not have maturity). It differs from silent partnership in the way that profit participation rights are used when ownership is diversified, while silent partnership is more common in cases of one to several owners.

Instruments that have most similar characteristics to equity are convertible bonds and bonds with warrants. There are numerous modalities of convertible bonds, such as callable or puttable bonds, mandatory convertible, pre-IPO convertible bonds, perpetual bonds, plain vanilla convertible, redemption premium convertible, bonds with warrants, etc. All of them have a unique characteristic depending on the investment agreement, but almost always they imply the right to convert debt into equity upon certain event (trigger) defined under the contract. This right is exercisable for a specified period and at a predetermined conversion or subscription rate.

Accountants have specified the rules for measuring these mezzanine instruments in standards where accounting financial instruments are presented (such as IAS 39 Finanical instruments issued by the IASB or SFAS No. 150 Accounting for Certain Financial Instruments with Characteristics of both Liabilities and Equity issued by FASB). Although accountants do recognize these instruments in accounting, they avoid calling them mezzanine. Instead, they use the term hybrid instruments (Knežević, 2009). Despite the importance of different names used for these instruments in finance and accounting, this area is still to be developed by accountants regarding their measurement and recognition.

\section{TYPICAL USAGE OF MEZZANINE FINANCE}

Mezzanine finance instruments are suitable for the companies with the experienced management team, solid business model, companies with good profitability and solid cash flow from operations, adequately positioned in the market, but not for the bank loan candidates. The last criterion makes these companies suitable candidates for mezzanine instruments. Mezzanine is not a substitute for a bank loan, but rather an additional source used by the companies whose credit rating is not good enough, which is why they are forced to consider other financing ideas. The mezzanine instruments can be used to repay bank or other long term debt, provide the equity base to increase the working capital and support business expansion, finance new capital expenditure projects, such as purchases of plant and equipment, as well as finance business model which is proven to be successful. When we consider the idea of the most suitable candidate for the mezzanine instruments, those would be the companies with stable growth margins and well-defined strategies. Nevertheless, it is not a suitable option for the businesses that are risky and startups, as it is an emerging business model. Also, it is not an appropriate solution for the businesses that operate with new technology and those trying to make new turn in their business.

A new market for mezzanine instruments has emerged over the last few decades in Europe. Its size varies across Europe and it depends primarily on the type of the economy and the proposed model of finance. In order to obtain mezzanine finance, SMEs should have sound financial and business information and reporting capabilities. This provides the investors with the possibility to evaluate and monitor key business risks. Mezzanine finance providers usually seek a return of up to 20 per cent on their investment, mostly as a result of large costs incurred when instruments are issued. In the case of highly standardized mezzanine finance products, the interest rates may be lower and these instruments are more attractive. They are sometimes used to finance innovations and technology transfer. While SMEs in some countries can choose from a wide range of different products, other countries still have a great deal of ground to make up in this area. Recently, mezzanine financing has been growing rather dramatically in Europe (Korver \& Ongena, 2008, p. 1613). Mezzanine instruments are composed of various types of instruments and some of them are listed below:

- a mixture of loan and equity financing,

- the owner of a certain business gives part of his/her ownership and expects return for the equity component,

- Convert the investment into equity if the business defaults on the loan payment.

The traditional suppliers of mezzanine finance are banks, specialized mezzanine funds, private equity funds, venture capital funds and business angels.

The criteria for the companies to obtain mezzanine finance are much more rigid than for loans, which is why these instruments are used in the transitional period of the company's life. They are used in two situations: to increase the company's valuation and re-arrange company's capital structure in order to buy one or more shareholders stake or pay some special dividends. The most attractive feature of mezzanine instruments is their ability to adapt to the needs of the company and adequately respond to them. The contract is usually signed when it is in compliance with the needs of both parties to the contract. Mezzanine instruments are frequently used to finance capital projects, but also as a source of finance of the company's own shares (treasury shares).

\section{PERSPECTIVE OF MEZZANINE INSTRUMENTS IN SERBIA}

Due to their high indebtedness, it is nowadays almost impossible for a growing number of companies in Serbia to borrow from commercial banks. Specifically, in cases where the company is highly leveraged and without collateral available, despite the good prospects of a profit and cash flow, it is unlikely that they will get a bank loan. The privatization model implemented in Serbia has led to further deterioration of the financial position of a certain number of companies (Ranković, 2000; Pavlović, 2008). Serbia has so far concluded a couple of arrangements where projects were funded by mezzanine capital (East Point Group, Serbia Broadband - Serbian cable network, Gomex). Several companies negotiated the usage of mezzanine capital, but such deals were abandoned. A wider use of mezzanine instruments is generally not expected even for the small number of large companies since they have a weak earning capacity. Also, systemic risk is still high. However, mezzanine instruments can be extremely attractive to the companies with poor financial position, competitive products and good profitability prospects. As a result of the chosen model of privatization, the number of such companies in Serbia is not negligible. Considering the fact that many of these companies are purchased for the purpose of selling their assets upon privatization, the number of companies with a good business model and no credit rating for the loan can be the reason for using mezzanine instruments. The usage of mezzanine instruments is strongly encouraged by the European Commission and we believe that the importance of these instruments in Serbia will be at a higher level once the small and medium-sized enterprises have reached their full development potential. Serbia is currently launching a series of initiatives in cooperation with the highest bodies in our country in order to intensify and promote the conditions for the development of mezzanine instruments. These activities should prepare Serbian enterprises to use mezzanine financing 
instruments. The underdevelopment of financial markets in Serbia could stimulate the usage of mezzanine instruments based on the contract. On the other hand, due to the poor financial position of the vast majority of companies, the use of mezzanine instruments for the purpose of acquiring other companies is questionable. Mezzanine investors believe the Serbian market is quite interesting because of the low competition in the investment segment in closed entities (private capital), which allows them to potentially make above-average yields. It is estimated that the major obstacle to mezzanine financing in Serbia is not a lack of prospective investors, but the unwillingness of the companies to use this form of finance, as well as lack of understanding of mezzanine instruments.

\section{CONCLUSION}

Mezzanine financing is potentially a good way to raise funds, but should not be considered a substitute for bank credit when the company's loan application has been denied. Since mezzanine instruments are based on their characteristics between debt and equity, it is common to generate higher returns than normal debt instruments and lower than normal required rate of return on capital for equity instruments. This type of financing should not be seen as a universal solution that fits all companies in all phases of their life cycle. The use of mezzanine instruments is suitable for the companies with necessary funds to finance development beyond the scope of assets that can be obtained by borrowing from banks or issuing debt financial instruments, with the characteristics such as stable business, good ratings, stable and predictable cash flows and respectful management. It is estimated that Serbia boasts considerable potential for the introduction of instruments with the characteristics of mezzanine.

\section{REFERENCES}

Bean, L. (2008). Mezzanine Financing: Is It for You? The Journal of Corporate Accounting and Finance, 19(2), 33-35. DOI: 10.1002/jcaf.20370

Credit Suisse. (2006). Mezzanine Finance - A Hybrid Instrument with a Future, Economic Briefing No. 42, Economic Research, Zurich.
European Commission. (2007). Mezzanine Finance: Final Report, Roundtable between bankers and SMEs. Available from: http://ec.europa.eu/enterprise/newsroom/cf/_getdocument.cfm?doc_id=1065, Retrieved December 01, 2012.

Farrell, H., \& Wright, M. (2008). A review of sampling and definitional issues in informal venture capital research. Venture Capital, 10(4), 331-353.

Gose, J. (2007). Mezzanine lenders gain leverage. National Real Estate Investor, 49(8), 31-34.

Knežević, G. (2009). Izazovi vrednovanja finansijskih instrumenata u uslovima finansijske krize. XL Nacionalni simpozijum sa međunarodnim učešćem, „40 godina računovodstva i poslovnih finansija - dometi i perspektive“, Zlatibor, 27-29 maj 2009, 433-460. (In Serbian)

Korver, M., \& Ongena, S. (2008). European mezzanine. Applied Financial Economics, 18(20), 1613-1622.

Ljumović, I., Pavlović, V., \& Milačić, S. (2013). Imaju li instrumenti mezanina perspektivu u Srbiji? Anali Ekonomskog fakulteta u Subotici, 49(30), 27-38. (In Serbian)

Marinković, S., Ljumović, I., \& Stojković, D. (2012). Going public and initial public offering: An exploratory study of motives from Serbian companies. Industrija, 40(2), 125-144.

McCormick, R., \& Creamer, H. (1987). Hybrid Corporate Securities: International Legal Aspects. London: Sweet and Maxwell.

Müller-Känel, O. (2009). Mezzanine Finance: Neue Perspektiven in der Unternehmensfinanzierung. Bern: Haupt.

Pavlović, V. (2008). Metodologija vrednovanja kapitala i usvojeni model privatizacije u Republici Srbiji. Računovodstvo, 1/2, 39-51. (In Serbian)

Pavlović, V., \& Muminović, S. (2010). Značaj razvoja finansijskih tržišta za srpsku privredu. Industrija, 38(4), 41-67. (In Serbian)

Ranković, J. (2000). Privatizacija i saniranje. Niško savetovanje: Izazovi transformacije u realnom i finansisjkom sektoru. Niš: Savez ekonomista Srbije. (In Serbian)

Tucker, M. (2006). Access to Finance in Europe. Local Economy, 21(1), 78-83. DOI: 10.1080/02690940500472566 